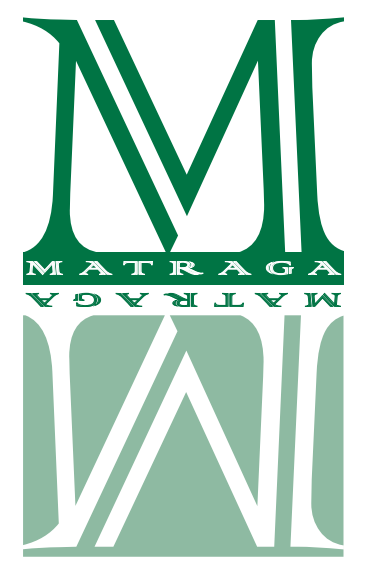

\title{
Games-Based Learning: An experience report in teaching English during the pandemic
}

\author{
Katherine Nunes Pereira Oliva Ortolani \\ Pontifícia Universidade Católica de São Paulo (PUC-SP) \\ https://orcid.org/0000-0001-6223-8493
}

Arthur Nogueira Ortolani

Universidade Cruzeiro do Sul

https://orcid.org/0000-0002-5623-1639

\begin{abstract}
COVID-19 has already taken over millions of lives and has brought the entire world to a halt. It has been a great challenge for teachers and students alike, especially for children. The area of education has reimagined itself. Children began to actively learn through the screens of their computers, tablets, and some, even cellphones. This article brings an experience report about strategies involving the principals and themes of Role-Playing Games used for online classes of English aimed at Brazilian children around the ages of five to nine years old. Role-playing games (at times also spelled as roleplaying games; abbreviated to RPG or RPGs) are games in which the people participating in them (players) assume the roles of characters within a fictional setting. The idea of using RPG strategies to retain the attention of children while teaching from afar, via Zoom, Skype or any other platform that allows the direct interaction between educator and student comes from RPGs' incredible capacity of transporting the mind of children to a different space, a space of attention and entertainment. As perceived by Tolomei (2017) and also shown in this experience report, motivation and engagement are enhanced through game mechanics. The technique also fulfills the need for human relationships, which has been taken away by COVID-19.
\end{abstract}

KEYWORDS: Teaching; Children; Role-playing games; COVID-19

\section{Aprendizagem baseada em games: um relato de experiência no} ensino de inglês durante a pandemia

\section{RESUMO}

COVID-19 provocou a morte de milhões de pessoas e fez o mundo inteiro parar. Tem sido um grande desafio para professores e alunos, principalmente para as crianças. A área da educação se reinventou. As crianças começaram a aprender ativamente por meio das telas de seus computadores, tablets e alguns até de seus celulares. Este artigo traz um relato de experiência sobre estratégias envolvendo os princípios e temas dos jogos de RPG usados em aulas online de inglês para crianças brasileiras de cinco a nove anos de idade. Os jogos de RPG são jogos nos quais as pessoas que participam deles assumem o papel de personagens em um cenário fictício. A ideia de usar estratégias de RPG para reter a atenção das crianças durante o ensino à distância, via Zoom, Skype ou qualquer outra plataforma que permita a interação direta entre educador e aluno vem da incrível capacidade dos jogos de RPG de transportar a mente das crianças para um espaço diferente, um espaço de atenção e entretenimento. Conforme percebido por Tolomei (2017) e também demonstrado neste relato de experiência, a motivação e o engajamento são potencializados por meio da mecânica do jogo. As técnicas também atendem à necessidade de relações interpessoais, que foi tirada pelo COVID-19.

PALAVRAS-CHAVE: Ensino; Crianças; Jogos de RPG; COVID-19 


\section{Introduction}

The year of 2020 may be remembered in history as a year of many things, protests, elections, violence, but probably at the top of the list would be the year of COVID-19. COVID-19 has already taken over 1.4 million human lives ${ }^{1}$ as of November of 2020 and has brought the entire world to a halt. This year has showed just about everyone that changes are not only possible, but also necessary. For instance, schools and many other teaching practices suffered major changes. It has been a great challenge for teachers and students alike, especially for children. The area of education has reimagined itself. Teachers and professors have begun to teach through online platforms that were once used by children and teenagers to play online games. Children began to actively learn through the screens of their computers, tablets, and some, even cellphones.

Teachers, professors, business owners and all of the areas associated with teaching were obligated to adapt due to the changes brought forth by COVID-19 and the attempts of containing it. Moments such as these prove the popular saying that "Necessity is the mother of inventions". The psychologist Lev Vygotsky defended that children learn by internalizing habits, vocabulary and ideas of the members whom they socialize with. Role-Playing Games (RPGs) work as a method for people to interact and explore their own imagination and, when applied to teaching, it helps to keep students involved and motivated. This article brings an experience report about strategies involving the principals and themes of Role-Playing Games used for online classes of English aimed at Brazilian children around the ages of five to nine years old.

Tolomei (2017) says that the lack of motivation is a hindrance to learning and children need to be involved and motivated in order to learn. It has been a challenge for parents and teachers alike to keep children motivated. Questions regarding their attention span, whether they are learning or not, and how to make a class interesting for them to participate have been risen.

The hobbies related to online gaming such as Role-Playing Games (RPGs) have had a boom in demand since people are spending more of their time at home and with their health in mind, the need for ways to socialize without physical contact has only increased. The fact that the world has been going through a long-lasting quarantine remains, and its effect is still felt throughout the world. The world of imagination that an RPG provides is also a way of escaping the sad reality the real world faces today.

The use of games in teaching has been part of education for a while. The idea of using RPG strategies to retain the attention of children while teaching from afar, via Zoom, Skype or any other platform that allows the direct interaction between educator and student comes from RPGs' incredible capacity of transporting the mind of children to a different space, a space of attention and entertainment.

The following sections aim at giving a brief explanation about children's learning process, what RPGs are and how they work, and the application of gaming in the learning process.

\footnotetext{
1 From: <worldometers.info/coronavirus/?>
} 


\section{Bridging a gap between teaching and learning with RPG techniques}

\subsection{Children's learning process}

When children are at school, teachers can use a plethora of different techniques, such as touching, eye contact, a quick word of encouragement or, in some situations, discouragement in order to control situations and events while still keeping them motivated and focused. Online teaching is more challenging in that sense; as to catch and hold onto the students' attention, the teachers no longer had the ability to use the techniques and tools that they were trained and used to using as many of them were no longer at their disposal. New necessities rose to the forefront of online teaching, for instance the need of a parent or guardian to be physically present next to the children so that they could say things such as "pay attention to your class!"; "your teacher is asking you a question!". These couple of examples were experienced by one of the researchers writing this article while teaching online classes. Such experience also allowed parents to be caught giving the answers to questions addressed to the students. It has been a challenge to have students engaged, paying attention, observing, memorizing, and understanding what is being taught. According to Elmore et al. (1996), Piaget (2013), Scardamalia \& Bereiter (1991) it is important that students set goals and assume responsibility for their own learning. Some activities are not possible without the active involvement and engagement of the learner. Teachers must help students build a natural desire to explore, to understand new things, encourage participation, problem solving and guide students to make their own decisions.

For researchers such as Brown et al. (1993), Collins et al. (1988), Rogoff (1990), Vygotsky (1980), social participation is how learning happens and children of this generation, according to Tolomei (2017), are not satisfied with just receiving knowledge, they need to test, to experience and to experiment with it. Through utilizing aspects of RPGs, such as storytelling and role playing moments, students have a chance to use their imagination, to interact and stay focused during a class of at least 45 minutes.

\subsection{What is RPG?}

Role-playing games (at times also spelled as roleplaying games; abbreviated to RPG or RPGs) are games in which the people participating in them (players) assume the roles of characters within a fictional setting ${ }^{2}$. As such, they are in charge of the actions of said characters within these games, either through literal acting, or other means of decision-making which vary widely from the specific games you are playing. At its core, RPGs are games in which the players create a collective storytelling narrative, not unlike the make-believe games we played as children.

The soul of these games rests in the imagination of its players. Where one can be anything from a peasant to a king/queen to a god/goddess. Roleplaying games began with "pen and paper" and are known to this day as Tabletop Role-Playing Games or TRPG, the most famous of which

${ }^{2}$ According to $<$ https://dnd.wizards.com/rules-introduction> 
is Dungeons \& Dragons, which is known and played globally by millions of people. In TRPG, actions and their results are determined by a series of structures placed by the designers of the game. However, one of the beauties of playing TRPGs is that you have the freedom to change the rules and structures of the game as per your liking. Once you do it, the game is truly yours.

There are several other forms of RPGs, such as, Live-Action Role-Playing or LARP; Massively Multiplayer Online Role-Playing Games or MMORPG; amongst numerous others. LARP takes the world created in one's imagination and transcends it to our physical world, where the players physically act out the story being told. MMORPGs are some of the many varieties of RPGs available in through the virtual media, such as Single-Player games.

Each platform has its own set of rules and regulations, and each game within said platforms have their own sets of rules and regulations. For instance, usually when playing TRPGs there is a person that assumes the role of Game Master (GM). The GM's role is very similar to the writer and the narrator of a book and of a judge. The GM will narrate the environment and setting the other players are in; they will also represent Non-Player Characters (NPCs), and in addition to that the GM must enforce the rules agreed upon by all players prior to the start of the game. As a rule of thumb though, the GM can alter the rules and regulations of the game for the betterment of the story and the fun of all players.

After the COVID-19 pandemic hit the world, a multitude of the so called "pen and paper" games found new ways to be played such as through the internet. They became Virtual Tabletop Role-Playing Games, which are nothing more than the regular TRPG played through a virtual medium such as ZOOM, Skype, DISCORD, Roll20, Fantasy Grounds, Foundry VTT and innumerous other sources.

The next section brings scientific information related to games applied to learning process.

\subsection{Gaming in the learning process}

Elkonin (1998) states that games are applied in society as a way to motivate group work and show tools for children and young people to learn. The use of gamification in the learning process is suggested to be a "search for the creation of experiences that are engaging and that keep players focused on their essence to learn something that positively impacts their performance ${ }^{3 \text { " }}$ (ALVES, 2015, p. 40, translated by the authors of this article). It is an opportunity to show how "the teaching practices supported by technology has great potential to renew education. The first step is to open up to the potential of technologies, allowing them to become the tools in the work of educating and teaching." (MASSÁRIO et. al. 2019, p. 4 translates by the authors of this article). In an RPG game, the GM is responsible for, as presented in Mäyrä (2017), describing the environment, while the players are supposed to describe what their characters

\footnotetext{
3 "busca da produção de experiências que sejam engajadoras e que mantenham os jogadores focados em sua essência para aprenderem algo que impacte positivamente a sua performance" (ALVES, 2015, p. 40)

4 "A prática docente amparada pelas tecnologias possui grande potencial para renovar a educação. 0 primeiro passo é abrir-se ao potencial das tecnologias, fazendo com que possam tornar-se parceiras no trabalho de educar e ensinar." (MASSÁRIO et. al. 2019, p. 4)
} 
want to do and then the GM narrates the results of the players actions according to set of rules that vary according to the game you play. The idea is for the teacher to assume the GM's role and the students the players. By doing this the students become part of a collective narrative with missions, responsibilities, and consequences to their actions. Their characters feel tired, hungry, they get hurt, buy equipment to go on their journeys, fight monsters, save kings, read letters, make their own decisions on how and where to go, while always being guided by the GM/teacher.

\section{Methodology}

\subsection{Material}

This section describes the list of materials used during class. For the classes, it has been used the following tools:

- Zoom, the online platform that allows student interaction through drawing on screen and helps teachers virtually write on the board.

- Images found on google images to represent the environment where the players are, such as villages, taverns or bakeries, forests, castles, areas of a house (kitchen, bedroom, bathroom).

- Images of possible friendly characters or of enemies.

- Images of equipment, such as swords, shields, maps, healing potions, ropes, hammers, rations, backpacks, canteen, clothes.

- A twenty-sided die and a four-sided die.

- Pages 2, 4, 5 and 10 from Adventure With Muk - An adventure activity book for players of all levels ${ }^{5}$

- Some realia when needed as per the story.

The classes last 45 minutes. There are three groups of four five-year-old children, and two groups of four nine-year-old children. The images for the classes are gathered on a power point presentation following the chronological order of the story. The idea for the story used in these classes was first inspired by the adventure written by Cameron Wright, entitled "The Cursed

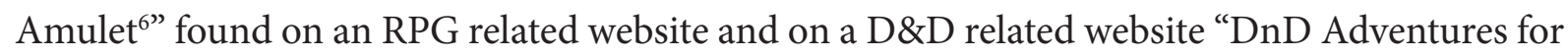
kids,", where one can find articles providing tips and suggestions on how to run an RPG game for children. The inspiration was the (cursed) amulet, the place where the roleplaying begins (a bakery), the first character that appears in the story (a dwarf), all according to this narration in the first page of the adventure:

Your story begins passing through the small village of Boulder Creek. You've been travelling along the main road for about 4 hours and decide to stop to get a bite to eat and refill your canteens. Boulder Creek is a small village situated in a meadow on the edge of the Emerald Forest. This village only

\footnotetext{
${ }^{5}$ Available at <https://dnd.wizards.com/products/tabletop-games/digital-only-rpg-products/adventure-muk>

${ }^{6}<$ https://rpggeek.com/image/5168703/cursed-amulet>

$7<$ https://dndadventuresforkids.com/>
} 
has a handful of wooden buildings, but the one that stands out the most is a red-painted building, not much bigger than a shack, that reads "Piece of Cake" above the serving window. You recognize this to be a bakery. A dozen or so mixed elves and humans in simple cloth clothing stand outfront impatiently waiting for their orders of fruit pie and fresh bread. A human couple holding empty wicker baskets are seen tapping their foot with an angry expression on their face while a distressed older Elven man in blue robes tries to get the owner's attention through the serving window. As you approach the bakery you see what appears to be a floating chef's hat flying back and forth on the other side of the serving window. Upon closer inspection you realize that this chefs hat is not flying, but resting atop a dwarves head. You realize this dwarf must be the owner. You hear him barking orders at his two employees, a male and female human in their late 20's. (WRIGHT, 2019, page 1)

The story was changed and vastly simplified due to the fact that the children's first language was not English, and the goal was to teach them the English language. From what was written by the adventure's author, the teacher kept a few elements only, such as the dwarf, the shack, the expression "piece of cake" and the "wooden building." First, images were shown to the kids for vocabulary teaching, then they were presented in the story as elements of the narrative.

A book written and illustrated by the company Wizards of the Coast in 2019, "Adventure With Muk - An adventure activity book for players of all levels" was used not only as inspiration, but also as a tool. It consists of an activity book with a story of a young goblin that has a friend and fights many monsters. In the book, kids have the opportunity to create creatures by mixing two animals. For instance, a bird plus a squirrel equals a "birdsquirrel". The book also brings a map which was used with the kids when looking for the amulet. Muk ends up as one of their friends during the adventure.

A power point presentation (PPT) is used every class, containing all the necessary images ${ }^{8}$. Vocabulary is taught prior to the telling of the story whenever new words are going to be used. The story is then briefly narrated by the teacher, students find themselves siting at a bakery, then two dwarves appear asking them for help. At this moment, students are able to introduce themselves, "My name is Felipe" to ask questions such as "what's your name?" "how are you?" and reply; "I'm fine", "I'm hungry". They are also asked to describe the dwarves, answering questions such as, "what color is his hair?", "is he fat or thin?", "is he short or tall?", "what are they wearing?", and then to describe themselves "My hair is dark, my eyes are brown". The teacher always models first using one of the NPCs, so students just have to imitate before they are able to voluntarily produce it for themselves.

The dwarves, played by the teacher, explain that they have to take an amulet to the king and that it is very dangerous to go by themselves. The teacher interprets the characters by changing their voices, which makes the students laugh and feel as if they were really talking to someone else. Once they accept the mission, the dwarves tell them that they have to go buy equipment for their journey, such as swords, shields, potions, armors, food and whatever else they might need for the adventure to come. It is possible to explore grammar and numbers, prompting questions

\footnotetext{
${ }^{8}$ Such images can be found on a series of websites that provide images that are of public domain (CCO), such as on the following website: <https://www.publicdomainpictures.net/>
} 
such as, "how many are there?" which in turn allows the teacher to teach the students how to properly reply using "there is" and "there are." The students choose their equipment, which is part of the vocabulary previously taught. Once they have done that, they are able to proceed to the next part of their adventure. They find monsters and other challenges throughout the story, which gives them an opportunity to use the equipment they have chosen. They take turns during the battle according to the number they got after rolling the twenty-sided die, which is called "rolling initiative" (which tracks the order of combat). The teacher says that the monster and students have a total number of hit points (HP), which is a number that quantifies their "life force," for once it reaches zero their characters go unconscious, possibly dying. Students usually are given $10 \mathrm{HP}$, monsters are given more or less depending on their sizes and challenge. Zoom allows children to draw on the screen, which at times will lead to cases where images are not even necessary, since they can use their imagination.

For the battles, both the teacher and the student roll a twenty-sided die to determine whether the attack hits or misses its target, be the monster hitting the player or the player hitting the monster. The success of their actions is determined by who rolls the higher number, the defender or the attacker. Then, if the attack hits, a four-sided die is rolled to determine how much HP the harmed party loses. It is a great chance to practice math while speaking English, having the students calculate what they now have after their loss, as in "what is 10 minus 3 ?" or " 10 minus 3 equals?" and the student completes the sentence. After plenty of times doing the same calculations, students are able to say the whole sentence for themselves, " 7 minus 2 equals 5 " and celebrate their victories or mourn their defeats.

Students have a chance to take turns during their rest, watching out for enemies, they encounter letters, where they are able to practice their reading skills (when age allows to do so) and giving them hints of where they have to go next. The teacher asks what they are doing during their turn on the watch and they practice the use of Present Continuous such as in "I am cleaning my sword", "I am eating my bread". The teacher always models first using one of the NPCs, so students just have to imitate before they are able to voluntarily produce it for themselves. They have a chance to apply future tense when asked to make plans for their next moves, "I will use the healing potion to heal my friend", "I will go to the castle and save the dragon". When in a tavern or a restaurant of some sort, they are exposed to opportunities to order food, provided with a simple menu made by the teacher where they are supposed to use the structure "I would like.... Even sicknesses can be taught after a simple meal at a bakery or tavern, by having one of the NPCs created by the teacher, such as the dwarves, role-play a situation in which they ended up eating more than they could handle and having a stomachache, falling on the floor and having a broken arm and so on.

\section{Final remarks}

This experience report aimed at sharing how children and teachers can benefit from RPG methods in order to drive motivation. It has helped children feel involved as they are placed as the heroes of the story. They are exposed to opportunities to develop their problem solving, decision 
making, and cohesive team-working skills, as this method does not promote competition amongst themselves, while also showing results in learning the language. As perceived by Tolomei (2017) and also shown in this experience report, motivation and engagement are enhanced through game mechanics, which goes along with Elkonin (1998) when stated that games can motivate group work and provide tools for learning.

The RPG methods used in this experience also concurs with what Alves (2015) says about the use of gamification techniques in teaching, due to engaging experiences that keep students/players focused and bringing positive impact to their performance with the language. The techniques also fulfill the need for human relationships, which has been taken away by COVID- 19 .

\section{REFERENCES}

ALVES, Flora. Gamification: como criar experiências de aprendizagem engajadoras. DVS editora, 2015.

BROWN, Ann L. et. al. Distributed expertise in the classroom. Distributed cognitions: Psychological and educational considerations, p. 188-228, 1993.

COLLINS, Allan; BROWN, John Seely; NEWMAN, Susan E. Cognitive apprenticeship: Teaching the craft of reading, writing and mathematics. Thinking: The Journal of Philosophy for Children, v. 8, n. 1, p. 2-10, 1988.

Dungeons \& Dragons. Rules introduction. 2020. Available at $<$ https://dnd.wizards.com/rules-introduction $>$ Accessed: Dec/21/2020.

Dungeons \& Dragons. Adventure with Muk. 2020. Available at $<$ https://dnd.wizards.com/products/tabletop-games/digital-only-rpg-products/adventure-muk>. Accessed: Dec/21/2020.

Dungeons \& Dragons. Adventures for kids. Available at $<$ https://dndadventuresforkids.com/>. Accessed: Dec/21/2020.

ELKONIN, Daniil B. Psicologia do jogo. Martins Fontes, 1998.

ELMORE, Richard F.; PETERSON, Penelope L.; MCCARTHEY, Sarah J. Restructuring in the classroom: Teaching, learning, and school organization. California: Jossey-Bass Inc., Publishers, 1996.

MASSÁRIO, Marcelo Schaedler, et al. Gamificação como prática de ensino. Research, Society and Development, v. 8, n. 7, p. e12871109-e12871109, 2019.

MÄYRÄ, Frans. Dialogue and interaction in role-playing games. Dialogue across Media, v. 28, p. 271, 2017.

PIAGET, Jean. Success and understanding. Routledge, 2013.

ROGOFF, Barbara. Apprenticeship in thinking: Cognitive development in social context. Oxford University Press, 1990.

RPGG. 2020. Available at <https://rpggeek.com/image/5168703/cursed-amulet>. Accessed: Dec/21/2020. 
SCARDAMALIA, Marlene; BEREITER, Carl. Higher levels of agency for children in knowledge building: A challenge for the design of new knowledge media. The Journal of the learning sciences, v. 1, n. 1, p. 37-68, 1991.

TOLOMEI, Bianca Vargas. A gamificação como estratégia de engajamento e motivação na educação. EAD em foco, v. 7, n. 2, 2017.

VYGOTSKY, Lev Semenovich. Mind in society: The development of higher psychological processes. Harvard University Press, 1980.

Worldmeters.com. 2020. Available at <https://www.worldometers.info/coronavirus/> Accessed: Dec/21/2020. 